\title{
Current Knowledge of Content and Composition of Oat Oil-Future Perspectives of Oat as Oil Source
}

\author{
Karol Banaś $^{1} \cdot$ Joanna Harasym ${ }^{1,2}$ (I) \\ Received: 20 May 2020 / Accepted: 29 September 2020 / Published online: 8 October 2020 \\ (C) The Author(s) 2020
}

\begin{abstract}
The oat oil composition is unique among cereals; however, the industrial exploitation of oat oil still needs more attention. The health claims authorized by the FDA and the EFSA have led to a significant increase in the industry's interest in oats as an industrial crop. The current focus is put on the extraction of fibre/beta-glucan or oat proteins. In contrast, the fat present in oats and especially its functional components do not attract sufficient industrial attention. The paper presents a concise analysis of the current state of knowledge about the content and composition of oat oil (perceived as oil as product, not fat content) regarding oil extraction methods and analysis. The profound study suggests that oil separation should be obviously taken into account during oat fractionation for industrial products. Such an approach will be in agreement with sustainable management of natural resources and should be taken into account when planning full utilization of each plant crop.
\end{abstract}

Keywords Oat oil $\cdot$ Oil extraction $\cdot$ Phospholipids $\cdot$ Glycolipids

\section{Introduction}

The world oat harvest in 2018 amounted to 23,412 tons per hectare while the area of oat cultivation in the whole globe in the years 2014-2018 ranged from 9.5 million ha to 10.1 million ha. Meanwhile, in Europe, a rising trend of area of oat harvested in the years 2015-2018 is observed (FAOSTAT, 10.08.2020). Such an opposite trend noted by FAOSTAT data suggests the intensive interest put in oat crop production in Europe (Fig. 1).

The amount of horses fed oats is constantly decreasing; therefore, the rise of cultivation area of oats can only be driven by recent findings regarding the oat ingredients.

In the past, oats were mainly treated as a phytosanitary plant or planted for horse feeding purposes (Gorash et al. 2017). Currently, oat grain is increasingly used in the food

Joanna Harasym

joanna.harasym@ue.wroc.pl

1 Department of Biotechnology and Food Analysis, Wrocław University of Economics and Business, Komandorska 118/120, 53-345 Wroclaw, Poland

2 Adaptive Food System Accelerator - Research Centre, Wrocław University of Economics and Business, Komandorska 118/120, 53-345 Wroclaw, Poland industry due to its rising use in exclusion diets, e.g. for coeliac patients (Gilissen et al. 2016; Harasym 2011) as well as in health benefits (Martínez-Villaluenga and Peñas 2017). In food production, oats are seen as a source of not only protein with the highest biological value but also minerals, vitamins, and dietary fibre (Piątkowska et al. 2010; Sang and Chu 2017), including soluble fibre fraction, especially $\beta$-glucans (Błaszczyk et al. 2015; Suchecka et al. 2015, 2016, 2017) and essential fatty acids (Halima et al. 2015; Piątkowska et al. 2010; Sahasrabudhe 1979; Zhou et al. 1999).

Oats in their unique and rich composition contain antioxidants and biomolecules (Halima et al. 2015) essential for health, compared with other basic cereals such as barley, wheat, and rice. Polyphenolic compounds, avenanthramides, tocochromanols, phytic acid, and EFAs including $\alpha$-linolenic acid, melatonin, inositol phosphates, phytosterols and the water-soluble $\beta$-glucans mentioned above offer a wide range of pharmacological application especially against civilization diseases, e.g. against cardiovascular diseases (Kawka and Achremowicz 2014; Zieliński et al. 2012).

Currently, oat varieties with different chemical composition are used in oat cultivation (Gorash et al. 2017). Research is also being conducted on the improvement of quality and increase in yield of varieties containing bioactive compounds (Kawka and Achremowicz 2014). Varieties rich in $\beta$ glucans and containing specific lipids and antioxidants are 


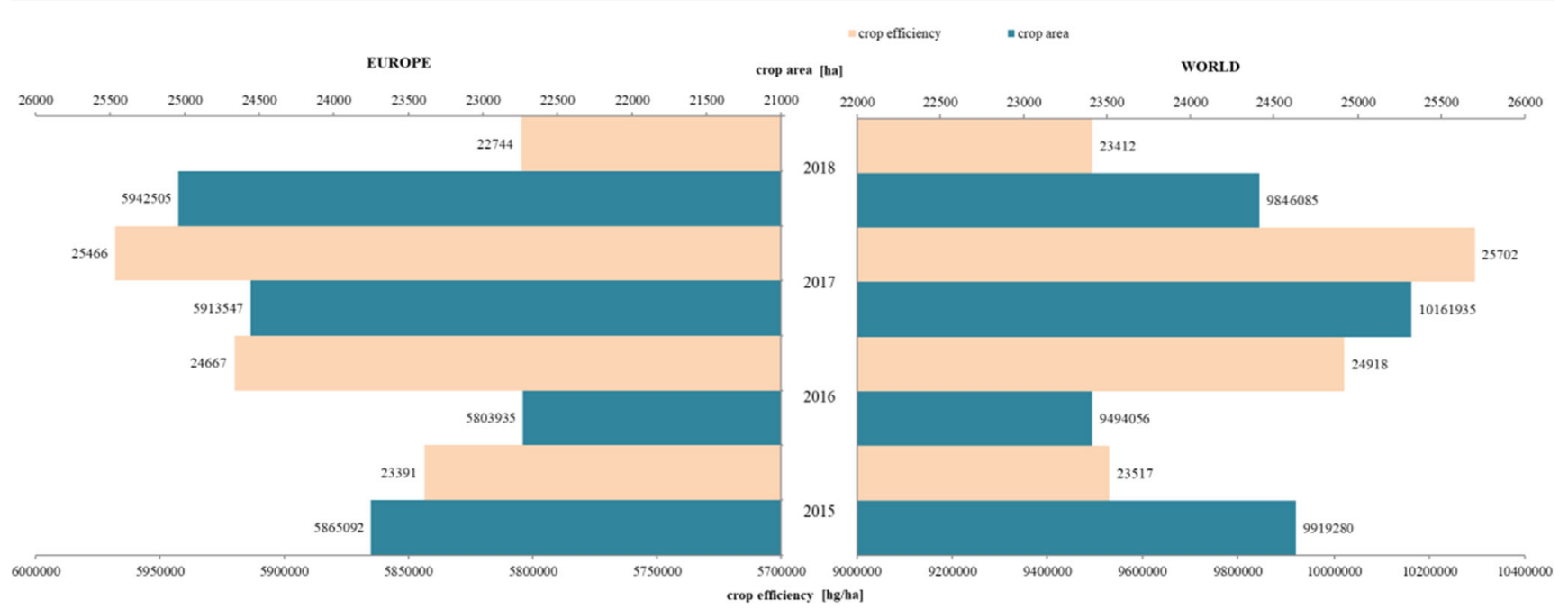

Fig. 1 Crop efficiency and crop area of oat cultivation from 2015 to 2018

useful for food and pharmaceutical industry, while feed producers prefer varieties containing higher amounts of protein and lipids (Kawka and Achremowicz 2014). The introduction of new, naked, and husked oat varieties into the cultivation creates much greater opportunities for their use in the food and pharmaceutical industries (Gorash et al. 2017).

Recent years have seen an increase in consumer knowledge and awareness of the nutrient content of oats (MartínezVillaluenga and Peñas 2017; Sang and Chu 2017), which has led to a greater demand for products based on this cereal (Rasane et al. 2013). Although the production of oats worldwide has declined over the last decades, innovation in the use of this plant is increasing, creating opportunities to increase the value of yields. New methods and techniques of oat grain fractionation make it possible to exploit its potential as a raw material in many industrial sectors. Oat grains as well as their preparations can be used to produce a new generation of products in the pharmaceutical industry (Wang et al. 2011), chemical industry (Kusch et al. 2011), cosmetic industry (Harasym 2016), food (Ballabio et al. 2011; Flander et al. 2007; Gupta et al. 2010) and for medicinal and dietary purposes (Ballabio et al. 2011) (Fig. 2).

The perception of being natural is the main advantage that attracts consumers and encourages them to buy oat products that contain many functional ingredients.

Oat grains consist mainly of starch (39-55\%), proteins (9$16 \%)$, lipids (2-18\%) and dietary fibre (20-39\%) (Frey and Holland 1999; Zhou et al. 1999). It has also been found that the oil contained in oats can have nutritional and technological potential (Price and Parsons 1975; Sahasrabudhe 1979). Oats were not used as a source of edible oil, because its amount in seeds is quite low compared with oilseeds, but it contains much higher levels of lipids than any other cereal grain, making it an excellent source of energy and unsaturated fatty acids (Wilde et al. 2019; Zhou et al. 1999).
Compared with other cereals, oat grains contain oil from 2 to $18 \%$ (Frey and Holland 1999; Halima et al. 2015). In 1979, Sahasrabudhe (1979) described the typical oat lipid composition in which they found the following: $51 \%$ of triacylglycerols, $7 \%$ of free fatty acids, $3 \%$ of sterols, $3 \%$ of sterile esters, $8 \%$ of glycolipids and $20 \%$ of phospholipids. Oat lipids can be divided into polar and non-polar fractions. Polar lipids are mainly glycolipids and phospholipids (Sahasrabudhe 1979). Non-polar lipids constitute about $80 \%$ of all lipids in oats and contain valuable fatty acids. The majority of them are palmitic acid $(20 \%)$, oleic acid (35\%) and linoleic acid (40\%) and fatsoluble antioxidants. Youngs et al. (1977) suggested that the content of free fatty acids depends on the preparation of samples for analysis. In a grain that is ground, the lipase activity increases, thus increasing the content of free fatty acids (Kawka and Achremowicz 2014; Peterson and Wood 1997). Important factors influencing the content of lipids and fatty acids in the grain are soil-climatic conditions and hereditary characteristics during the vegetation of the plant (Frey and Hammond 1975; Karunajeewa et al. 1989; Pisulewska et al. 2011).

At present, oat oil on a larger scale is obtained during the bio-refining of oat grains to obtain more functional components such as $\beta$-glucans, while it is treated as a by-product of the target production (Liu 2014; Sibakov et al. 2011). Biorefining as a process of sustainable synergistic processing of biomass into a range of marketable food and feed ingredients, products (chemicals, materials) and energy (fuels, electricity, heat) may in the future become a key method for the production of oat oil, which can be used in many industrial areas (Harasym 2015). At present, the number of product biorefineries is limited due to the fact that some of the key technologies that are part of biorefining technology are insufficiently developed to implement in the commercial market; additionally, there is still no sustainable use of biomass in both 
Fig. 2 Volume vs. value of product groups obtained from oat

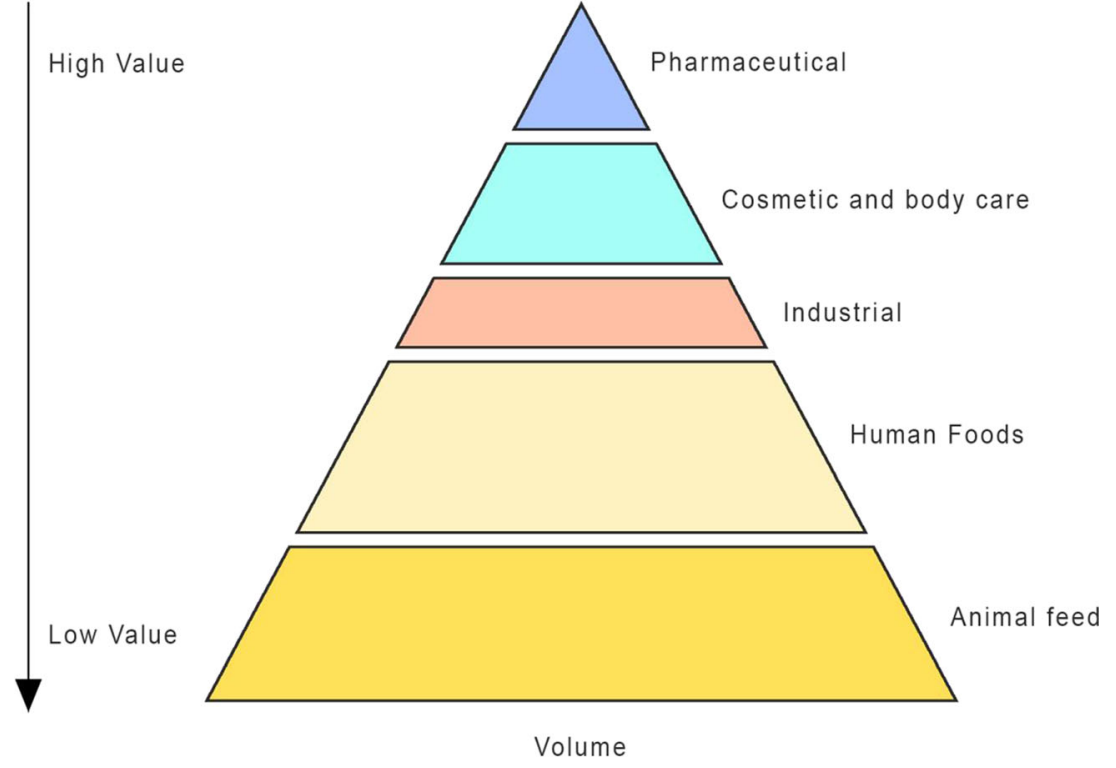

as phosphatides. The structure of these compounds is mainly based on phosphatidic acids, which are 1,2-diacylated 3glicerophosphoric acid esters associated with organic bases or other groups. Price and Parsons (1975) using column chromatography and thin layer chromatography (TLC) found that L- $\alpha$-phosphatidylcholine (PC), L- $\alpha$-phosphatidyl ethanolamine (PE) and L- $\alpha$-lysophosphatidylcholine (Lyso-PC) are the most numerous phospholipids in the oat grains analysed). Sahasrabudhe, using the same method in the study of six different oat varieties, determined the profile of oat phosphatides: L- $\alpha$-lysophosphatidyl ethanolamine (Lyso-PE) (20.4\%), L- $\alpha$ phosphatidyl ethanolamine (PE) (14.8\%), L- $\alpha$-phosphatidyl glycerol (PG) (9.5\%), L- $\alpha$-phosphatidylinositol (PI) (3.9\%) and L- $\alpha$-phosphatidylserine (PS) (3.2\%), stating that the L- $\alpha$ phosphatidylcholine (PC) content $(29.9 \%)$ is the highest, thus confirming that the phospholipid content of different oat varieties is similar (Montealegre et al. 2012; Sahasrabudhe 1979).

The amount of phospholipids in oats shows a high variability from 6 to 26\% of all lipids (Zhou et al. 1999). The main building block of this part of the lipids is phosphatidylcholine (45-51\% of all phospholipids) (Youngs et al. 1977). The others are mainly phosphatidyl ethanolamine and phosphatidyl glycerol (Holmback et al. 2001). Studies have also confirmed that the phospholipid content of different oat varieties is similar (Sahasrabudhe 1979). Some studies have shown that oat-based emulsifiers have a high economic potential in the food industry due to their better sensory and physical properties than soya-based products. Phospholipids obtained from oats improve the bread volume, grain size, texture and delay the ageing process of bread (Erazo-Castrejón et al. 2001). To date, there has been little research on the content of phospholipids in oat lipids despite the fact that the role of phospholipids in the human body is significant because they participate in the growth of all body cells and are part of cell 
membranes (Gangopadhyay et al. 2015; Montealegre et al. 2012). Recent research shows that phosphatides, i.e. phosphatidylcholine and $\mathrm{N}$-acylphosphatidyl ethanolamine, can be used to create natural oat-based lecithin (Younes et al. 2020).

\section{Glycolipids}

Polar fractions of lipids from cereals show high glycolipid content. Compounds that can be distinguished especially in this group of fats are as follows: monogalactosyldiacylglycerols (MGDG), digalactosyldiacylglycerols (DGDG) and sulpholipids (SQDG). Digalactosyldiacylglycerols build membranes of chloroplasts of higher plants and other organelles in the cell. They are found in all tissues involved in photosynthesis, including higher plants, algae and some bacteria. The glycolipid content of oat oil ranges from 7 to $12 \%$. Oat oil obtained by extraction of oat flour with hexane or ethanol contains a very high level of DGDG and is the most common glycolipid found in oat seeds (Andersson et al. 1997; Doehlert et al. 2010; Moreau et al. 2008). Welch reports that oat glycolipids have viscosity-reducing properties and are therefore used as emulsifiers in chocolate products (Welch 1977). Digalactosyldiacylglycerols are amphiphilic and may form lamellar crystalline phases. Recent studies have shown that the polar oat lipid fraction containing monogalactosyldiacylglycerols (MGDG) and digalactosyldiacylglycerols (DGDG) can be a promising emulsifier and form a water-oil emulsion due to their achievable anti-coalescence stability and good creaming prognosis. They can therefore be used to form lipid aggregates, such as water-oil or liposome emulsions. The latter are interesting for nutritional and cosmetic purposes and can be used in pharmaceutical applications (Moreau et al. 2008). Similar to phospholipids, glycolipids can be used to produce natural oat lecithin (Younes et al. 2020) due to their polar properties.

\section{Oat Lecithin}

Emulsion-based foods and beverages are thermodynamically unstable systems that tend to split into unmixable phases. To stop this process, manufacturers add emulsifiers, usually of synthetic origin, to such food products. However, it is the 'natural' products that do not contain synthetic food additives that are of greatest interest to consumers today (McClements and Gumus 2016; Ralla et al. 2018). In current dietary trends, the composition of food products is becoming a key issue for the consumer, which also translates into the choice of the right emulsifier to affect the stability and then the quality of the product. The increase in diversity on the food market forces the search for new solutions in the field of food preservation; therefore, there is a constant demand for emulsifiers with new properties. The answer to this may be new emulsifiers obtained by extraction of polar lipids from previously overlooked sources, such as oats (McClements 2015; Younes et al. 2020). The European Food Safety Authority on Food and Flavour Additives (FAF) in its scientific opinion proposed the use of oat lecithin as a safe food additive in the proposed category 'Cocoa and chocolate products'. Oat lecithin as an additive is an oil extracted by means of ethanol from oat grains. This oil is then fractionated to obtain lipids with greater polarity. The lecithin thus obtained is yellow-brown in colour and has a taste of oat flakes. Oat lecithin consists mainly of non-polar lipids $(58 \% \mathrm{w} / \mathrm{w})$ and polar lipids $(35 \% \mathrm{w} / \mathrm{w})$. The non-polar fraction consists mainly of triglycerides while the polar lipids consist of $20-25 \%$ glycolipids (monogalactosyldiacylglycerols (MGDG) and digalactosyldiacylglycerols (DGDG)) and 15-20\% phospholipids including phosphatidylcholine and $N$-acylphosphatidyl ethanolamine. This lecithin also contains saturated (mainly palmitic and steric), monounsaturated (oleic) and polyunsaturated (linoleic and alpha-linolenic) fatty acids. When used as a food additive, oat lecithin is expected to undergo the same hydrolysis and biotransformation in the gastrointestinal tract to metabolites, as is the case for the digestion of other edible oils and esterified fatty acids and lecithin (E322). In addition, Younes and others report that this additive does not show genotoxic concentrations that could cause cellular mutagenic growth and, due to the nature of the formulation (bio-refinement), no allergic risk is expected, as is the case with soyabased emulsifiers and chicken eggs (Younes et al. 2020). Oat lecithin, which is also an oat oil, and which is mainly composed of non-polar lipids, may also provide a medium for the compounds with antioxidant potential dissolved in them (Guan et al. 2018; Peterson 2001). Recent studies show that preparations based on oat oil can have a potential protective effect against certain pathological conditions due to their antioxidant properties (Halima et al. 2014; Tong et al. 2014).

\section{Oat Oil Antioxidant Activity}

Oat oil is a source of natural antioxidants such as tocopherols, alk(en)iloresorcinols, phenolic acids and their derivatives and avenanthramides, which are unique to oats and do not occur in any other cereals (Brindzová et al. 2008). Phenolic compounds have a health-promoting potential due to their antiinflammatory and antioxidant effects. The already mentioned $\beta$-glucans, which also have an antioxidant effect, are contained in soluble fractions of dietary fibre and take part in glucoregulation and cause a decrease in cholesterol levels in humans (Harasym 2011). Fat-soluble tocopherols, tocotrienols and vitamin $\mathrm{E}$ are compounds that are biologically active due to their ability to give phenolic hydrogen atoms to free radicals, which allows to interrupt destructive chain reactions and thus inhibits the growth of cancer cells (Halima et al. 2015). The most characteristic group of 
antioxidants contained in oats are avenanthramides. These compounds are phenolic derivatives consisting of amides of hydroxycinnamic acid and hydroxyanthranilic acid. At least 20 different types of combinations of phenolic compounds with anthranilic acid derivatives present in oats are known, but their chemical structure has not been fully identified. Avenanthramides show anti-inflammatory, antiatherosclerotic effects, prevent itching of the skin and inhibit the production of proinflammatory cytokines (Liu 2014). Oat oil also contains such antioxidants as: organic acids including coffee acid, ferulic acid, $p$-hydroxybenzoic acid, vanilla acid and sterols and flavonoids. The use of modern food processing techniques, i.e. pressure, ultrasonic, liquid or enzymatic extraction, can ensure the isolation of bioactive compounds from the oat matrix. According to epidemiological and biological studies, the consumption of oats has a beneficial effect on health by reducing oxidative stress and chronic age-related diseases and has anti-cancerogenic properties (Gangopadhyay et al. 2015). Antioxidants contained in oats can also contribute to the stability and taste of food products (Peterson 2001). Further research and development is needed to identify costeffective ways of fractionating the rich nutrients contained in oats that can be used in various industries and, through their enormous potential and empirical value, attract consumers.

\section{Oat Oil Recovery and Analytics}

Different methods are used for the analysis of oat lipids, which may concern the determination of the total fraction as well as individual groups of lipids. The complexity of these methods is determined by the type of lipid fraction to be determined (total, free, bound), additionally, depending on the method of measurement, which can be carried out directly on the whole grain intact or after the initial extraction of grains, groats or oat flour. The choice of method for the determination of a given lipid fraction depends on the purpose of the analysis. The total amount of oat lipids equivalent to oil or fat is determined by extraction, spectroscopy or analysis of the fatty acid profile by chromatography (Zhou et al. 1999). The following Table 1 shows sample results which show significant differences in the total content as well as in individual components of oat oil depending on the solvent systems used.

\section{Solvent Extraction Methods}

Solvent extraction is the most common method used to determine lipid content (Frey and Hammond 1975; Peterson and Wood 1997; Price and Parsons 1975; Sahasrabudhe 1979; Youngs et al. 1977). Extraction methods with gravimetric measurement using the Soxhlet apparatus or Goldfish systems are classical techniques for the isolation of fats from solid samples, e.g. ground oat groats (Zhou et al. 1999). The solvent systems used by the extractors are very diverse, ranging from single-phase non-polar solvents to multiphase polar mixtures e.g. WSB (water-saturated n-butanol), which ensure the selective separation of the fat fraction. Nevertheless, there are few solvent systems that extract fats effectively. Non-polar solvents such as hexane or ether are effective for the isolation of so-called inert fats from cereal grains, while they are weak solvents for polar lipids, in particular phospholipids bound to cell membranes, which are effectively extracted by polar solvents (Zhou et al. 1999). Sahasrabudhe examined seven solvent extraction systems and showed significant differences in total lipid content and for different lipid groups. Table 2 below shows the results of the total oat oil content tests depending on the purpose of the test and the type of oat samples for polar solvent extraction.

\section{Extraction Methods with Supercritical Carbon Dioxide}

Recent discoveries prove that extraction with supercritical carbon dioxide $\left(\mathrm{SC}-\mathrm{CO}_{2}\right)$ (Pisulewska et al. 2011) may be an effective method to extract non-polar oat lipids in the future. Andersson et al. using this type of extraction developed the process of obtaining digalactosyldiacylglycerols (DGDG) from oats, thus confirming that this method can be used to extract selected components of oat oil (Andersson et al. 1997). By optimizing the fractionation process on the nozzle, to which two streams, a solution of oat oil and supercritical carbon dioxide is fed coaxially. During the extraction process, a spray jet is produced, which facilitates contact with the

Table 1 Total lipid content and lipid composition extracted by various solvent systems in groat of Hinoat variety

\begin{tabular}{llllllll}
\hline & Ethanol & Methanol (85\%) & WSB & Chloroform/methanol (2:1) & $n$-hexane/diethyl ether (8:2) & Isopropanol & $n$-hexane \\
\hline Total lipid content & 8.84 & 8.03 & 6.93 & 6.31 & 6.29 & 5.96 & 5.57 \\
Sterol esters & 2.04 & tcs & 2.09 & 0.13 & 0.64 & 3.61 & nd \\
Triacylglycerols & 3.58 & 3.19 & 3.13 & 3.39 & 1.3 & 3.21 & 3.61 \\
Partial glycerides & 1.09 & 1.5 & 0.67 & 0.68 & 0.34 & 0.18 \\
Glycolipids & 0.38 & 0.68 & 0.10 & 0.60 & 0.38 & 0.49 & 0.08 \\
Phospholipids & 1.69 & 2.64 & 0.92 & 1.55 & 0.31 \\
\hline
\end{tabular}

$n d$ not detected, $t c s$ traces, WSB water saturated butanol (Sahasrabudhe 1979) 


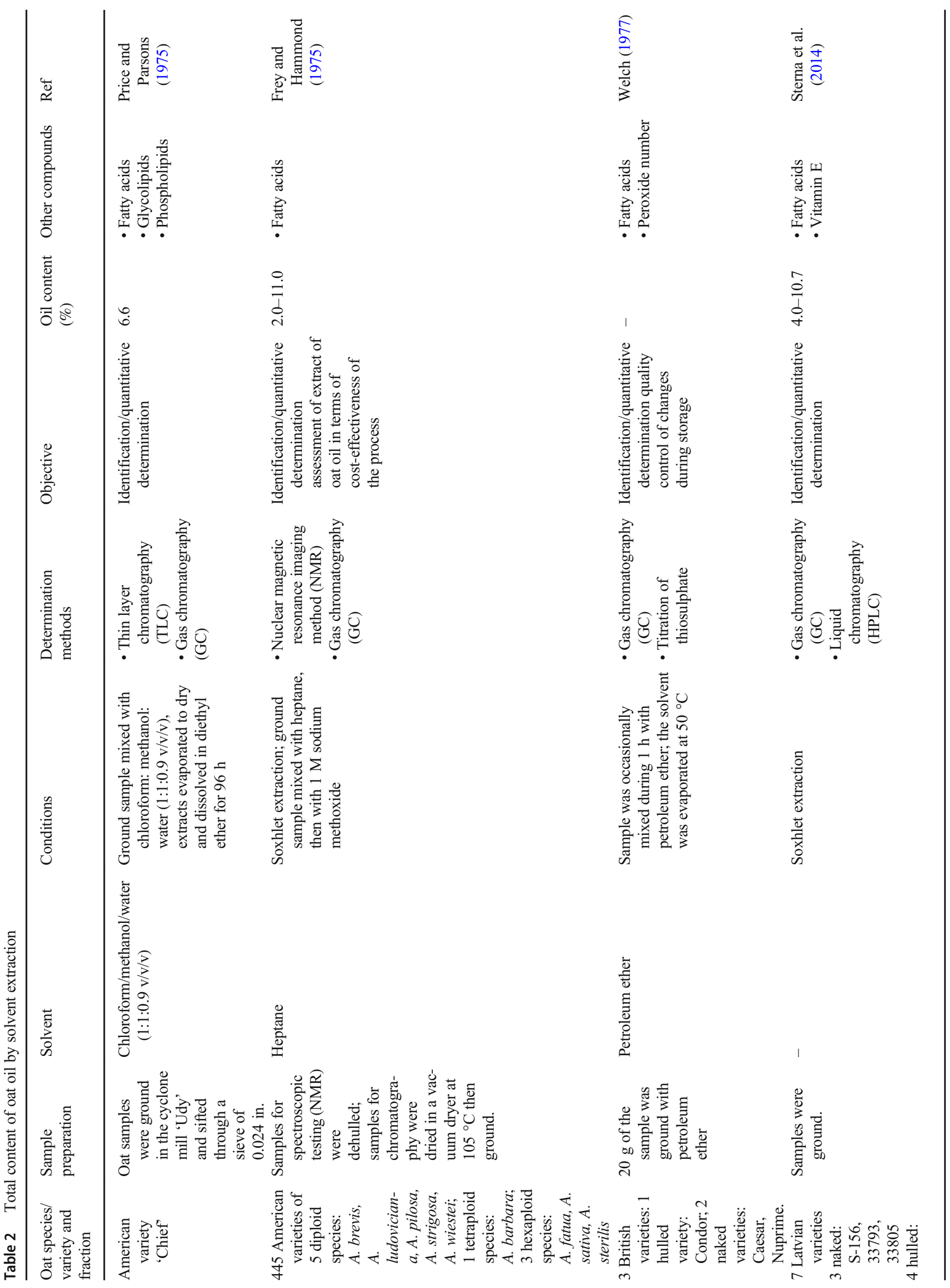




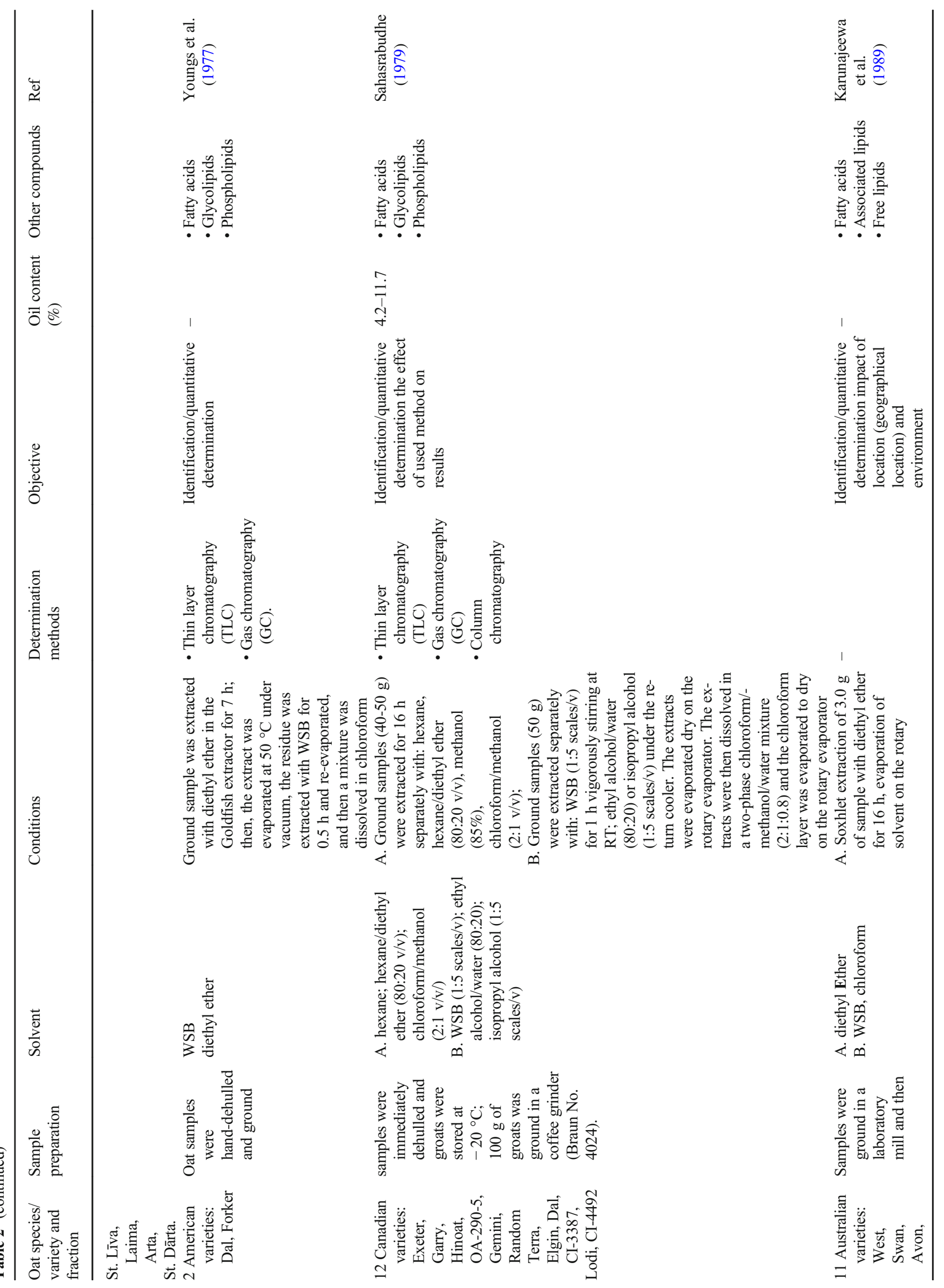




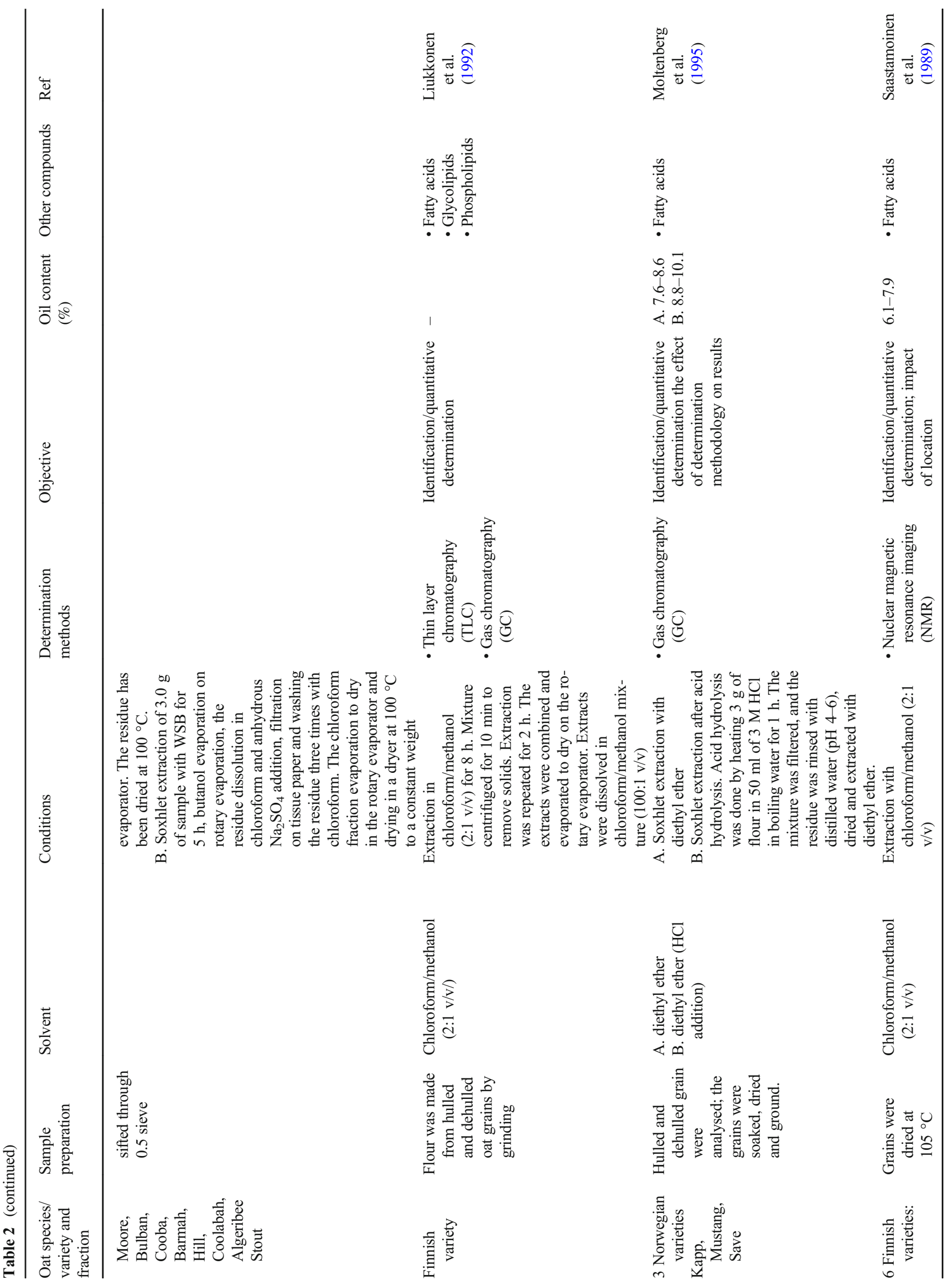




\begin{tabular}{|c|c|c|c|c|}
\hline 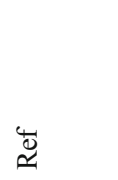 & & 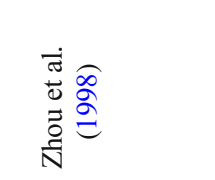 & 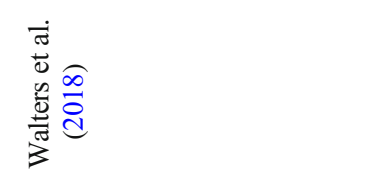 & 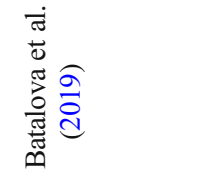 \\
\hline 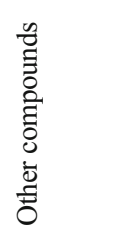 & & 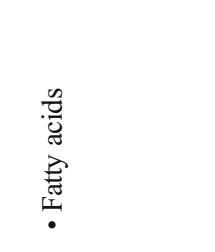 & 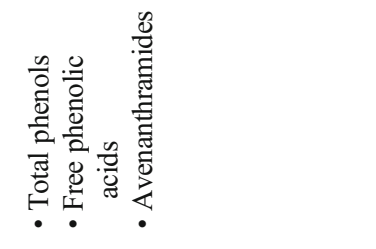 & 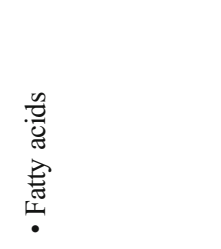 \\
\hline 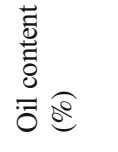 & & 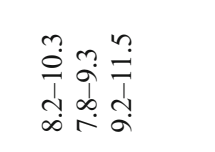 & & $\begin{array}{l}\hat{j} \\
\dot{\alpha}\end{array}$ \\
\hline 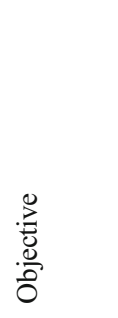 & 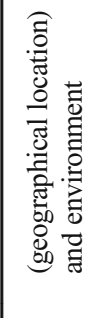 & 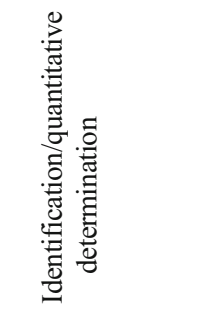 & 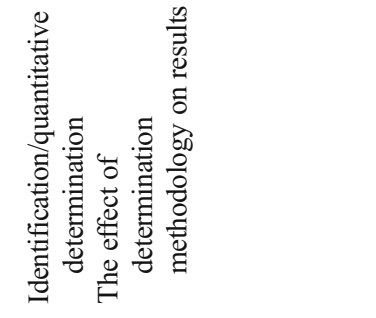 & 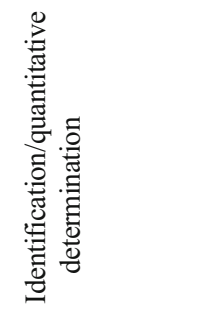 \\
\hline 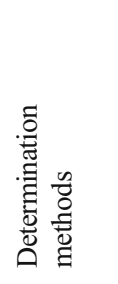 & 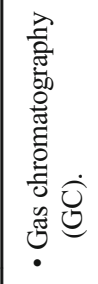 & 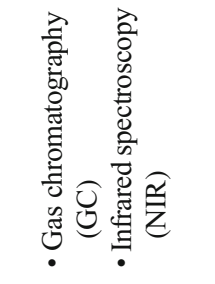 & 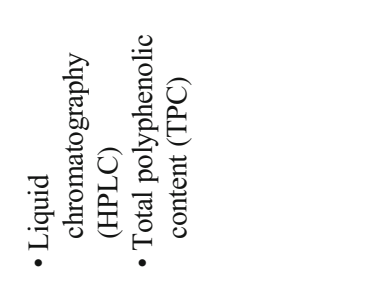 & 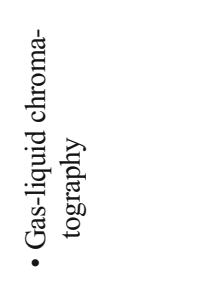 \\
\hline 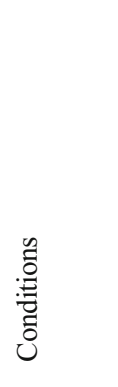 & & 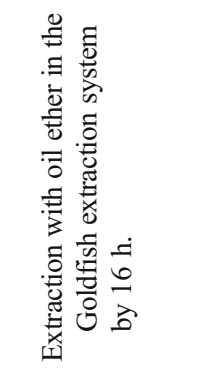 & 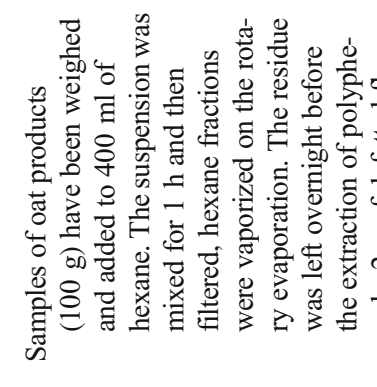 & 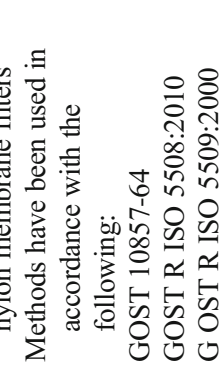 \\
\hline $\begin{array}{l}\overrightarrow{0} \\
\frac{\overrightarrow{0}}{0} \\
\frac{2}{0}\end{array}$ & & 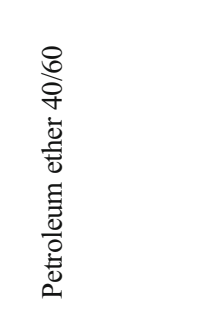 & 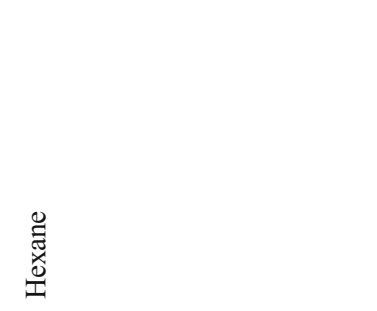 & 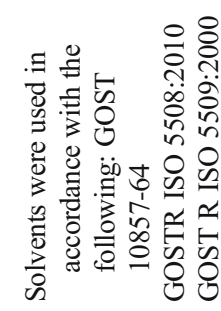 \\
\hline 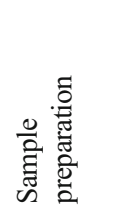 & & 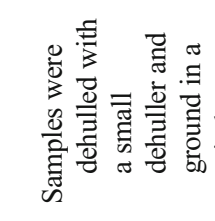 & 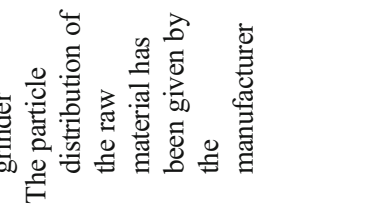 & 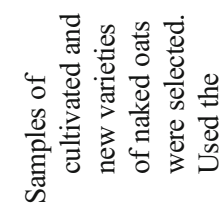 \\
\hline 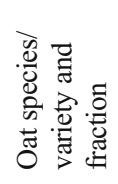 & 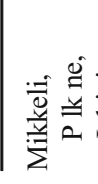 & 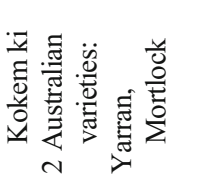 & 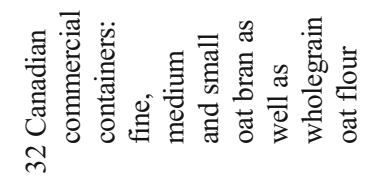 & 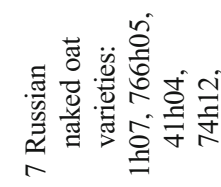 \\
\hline
\end{tabular}




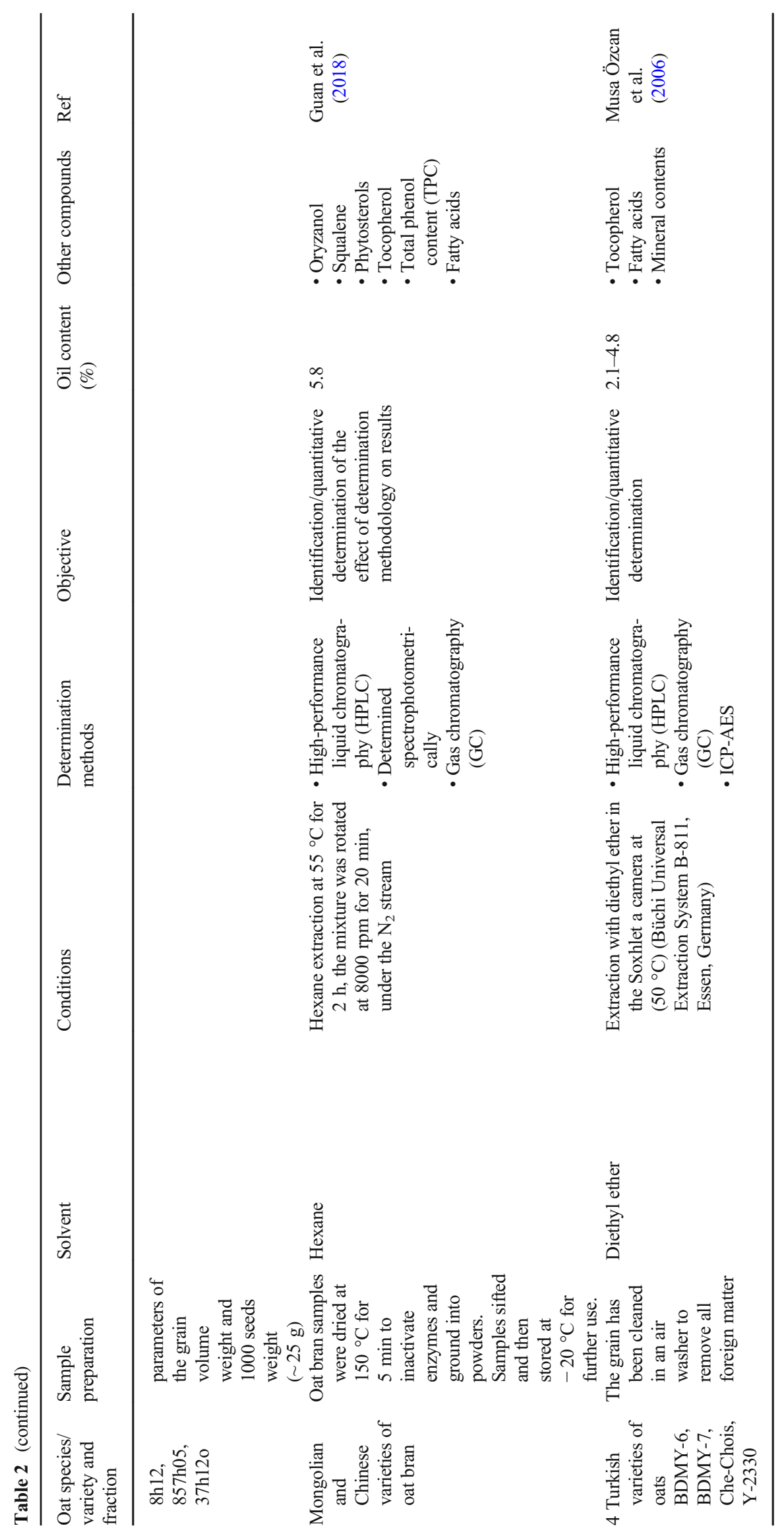


extractor. In this case, the triacylglycerols (TG) are dissolved in $\mathrm{CO}_{2}$, while the target product, digalactosyldiacylglycerols (DGDG), remains in the system (Andersson et al. 1997). Furthermore, by controlling the extraction process by adding a co-solvent, e.g. ethanol or isopropanol, it is possible to isolate the polar fraction of lipids (Forssel et al. 1992). Aro et al. (2007) developed a method to produce the polar oat lipid fraction by adding polar ethanol, which increased the amount of extracted polar components from grains and oat flakes. Table 3 below shows the results of the total content of oat oil depending on the purpose of the study and the type of oat samples for extraction with supercritical carbon dioxide $\left(\mathrm{SC}-\mathrm{CO}_{2}\right)$.

\section{Chromatographic Methods for Analysis}

Chromatography as an analytical technique for separating and determining the components of oat oil was used in the 1970s and early 1980s. These methods belong to planar chromatography and allow convenient fractionation of total fat content in triacylglycerols, phospholipids, glycolipids, free fatty acids and sterols. Sahasrabudhe has determined the lipid composition in oat oil by column chromatography and thin layer chromatography (TLC) (Sahasrabudhe 1979). However, in most cases, the use of these methods to characterize the lipids in oats was excluded due to the different nature of the components and the limitations of the analytical technique, such as the repeatability of results, changes in the composition of the mobile phase during the analysis or band scattering on the chromatogram caused by a decrease in the speed of the mobile phase with distance travelled (Price and Parsons 1975). In order to determine more accurately the composition of oat oil, chromatographic methods are currently used which, depending on the type of eluent, are divided into liquid chromatography (HPLC) and gas chromatography (GC).

Gas chromatography (GC) is used to detect and identify the components of a compound mixture. This technique is very similar to fractional distillation, separating the components of a mixture based on the differences in the boiling points of the substance, which are carried out in a gaseous form and then, using a carrier gas (mobile phase), transferred to the column where the separation of the mixture follows. GC is a reliable separation method because it provides a very accurate quantitative analysis of the fatty acids contained in oat oil. Methanolysis can produce methyl esters of fatty acids which have a relatively high volatility, making their analysis by GC fast (Zhou et al. 1998). Welch using acid methanolysis in the preparation of samples for chromatographic tests estimated the exact content of fatty acids in oat oil. Compared with previous chromatographic measurements, this method has proven to be more convenient, faster and can be used on small quantities of oil samples for routine composition tests (Moltenberg et al. 1995; Sterna et al. 2014; Welch 1977).
Oat oil components with polar properties, such as glycolipids and phospholipids, are determined using more selective and precise high-performance liquid chromatography (HPLC) (Sterna et al. 2014). In this method, the mobile phase (eluent) is made up of single solvents or mixtures of solvents. The eluent, which is introduced into the column, also includes the components of the separated mixture. The choice of the mobile phase must take into account the composition of the separated mixture, the type of detector and the filling of the column. This method has been successfully used by Moreau et al. to determine the polar fraction of lipids in oat oil (Moreau et al. 2008). Liquid chromatography (HPLC) as well as gas chromatography $(\mathrm{GC})$ are fast, reproducible and precise in the separation of compounds thanks to automation, but expensive due to the apparatus (detectors, columns) and the large quantities of harmful solvents and expensive standard substances used in the analysis.

\section{Spectroscopic Methods for Analysis}

Spectroscopic studies of lipid content offer the advantages of direct and rapid measurement for samples, e.g. grain, flour and chopped grain without prior preparation with the possibility of simultaneous analysis of composition (Saastamoinen et al. 1989). Brown and Craddock used nuclear magnetic resonance (NMR) to determine the oil content of 4533 samples of cut grain. The lipid content measured by this method was comparable with the data obtained during the determination of fats by non-polar solvent extraction (Brown and Craddock 1972). This method can also be successfully used for direct lipid analysis of the lipid composition of oat oil samples previously obtained by extraction. Manolache et al. determined the lipid composition of six oat oil samples using $1 \mathrm{H}-\mathrm{NMR}$ by direct measurement without prior processing into fat derivatives. This method made it possible to determine the content of fatty acids (trinitrate, dinitrate, monounsaturated and saturated) contained in oat oil, thus making it possible to distinguish the oil samples and to assess them qualitatively quickly. The results obtained in the future may be used for authenticity tests for different types of cereals, as well as for pseudo-grains (Manolache et al. 2013).

Other spectroscopic methods for determining the composition of cereals include techniques based on the measurement of near, medium and far infrared oscillatory spectra. Law et al. using far infrared (NIR) determined the protein moisture and fat content of grain. Over the next decades, this method has become one of the most used methods for continuous monitoring and control of product quality in the food industry. The infrared spectroscopic examination enables rapid analysis of samples without prior preparation for measurement and is also non-invasive. The advantages are also low costs and no use of harmful organic solvents in the determination. In addition to these advantages, this method has one major disadvantage due 


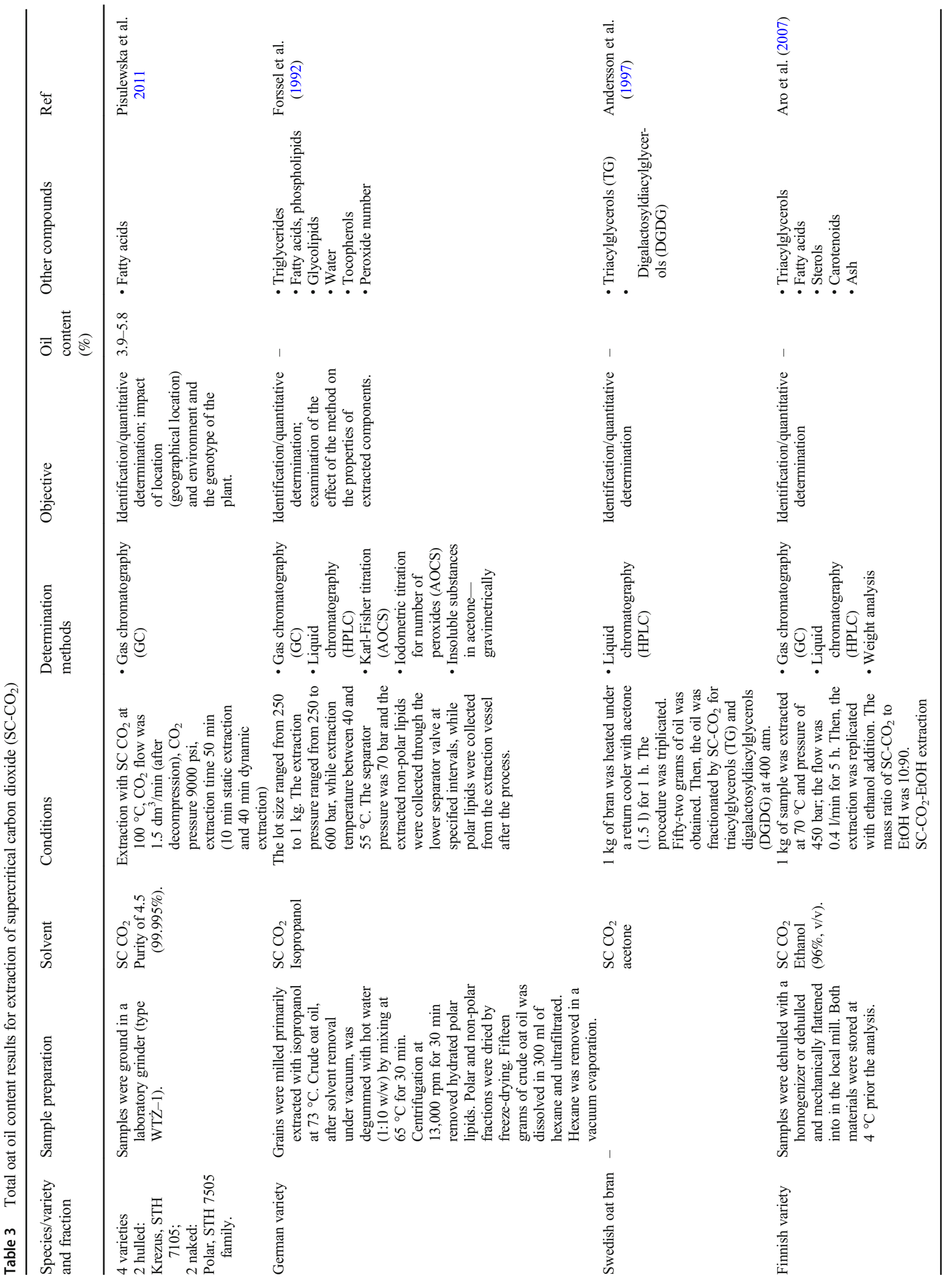




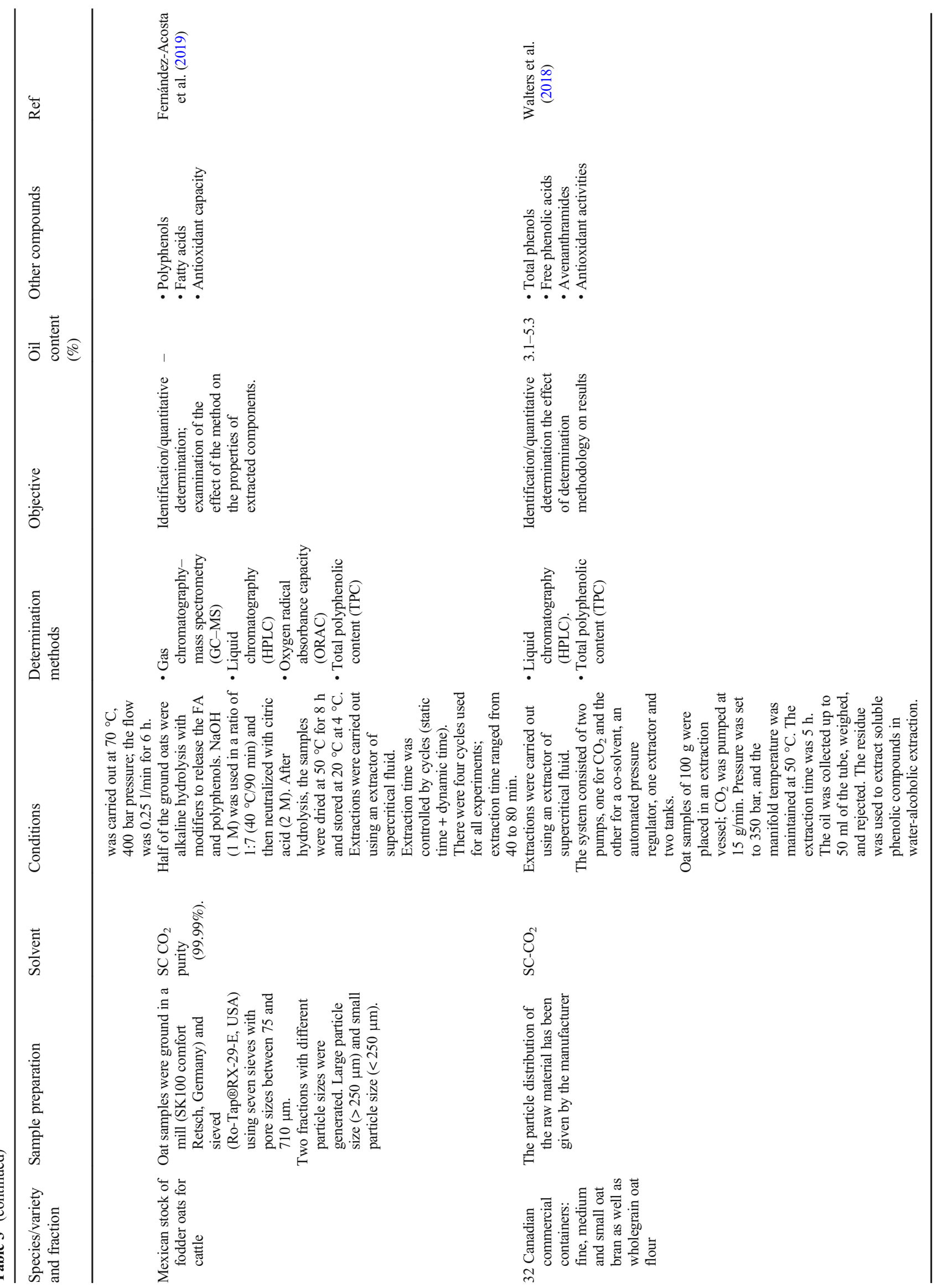


to the difficulty to interpret raw spectra, which often requires knowledge of advanced techniques (Roggo et al. 2007). Most near-infrared (NIR) oil determinations are based on the examination of the bands at 1722, 2306, and $2346 \mathrm{~nm}$, which correspond to the combination vibrations for the first supernatant $(\mathrm{CH} 2) n>4$ and similar type (Zhou et al. 1999). So far, few studies using NIR method for the measurement of oat components and its application in routine analyses have been published. This technique can be successfully used for the determination of fat and protein content in oats (Lemons et al. 2008).

Measurement in the mid-infrared (MIR) range, which covers the range from 400 to $4000 / \mathrm{cm}$, as well as Raman scattering are good tools for testing and identifying lipids. These methods allow to easily analyse the composition of mixtures by assigning reference bands for the tested compound. In addition to determining the nature of a given substance, quantitative analyses can also be performed. These techniques allow the examination of important parameters concerning lipid mixtures such as the degree of lipid unsaturation, the presence of trans $\mathrm{C}=\mathrm{C}$ isomers and the type of fats present in the sample. Manolache et al. examined six oat oil samples in the medium infrared range. The area between 3050 and $4000 / \mathrm{cm}$ was eliminated as it had no significant effect on the test result (water and noise band). Six bands were obtained from the spectral range of 2800 and $3050 / \mathrm{cm}$, while between 600 and $1800 / \mathrm{cm}$, the next twenty-five most important bands were derived from specific bond vibrations and $\mathrm{CHn}$ groups entering the structures of the tested lipids. In total, each of the measured spectra was represented by thirtyone characteristic bands (Manolache et al. 2013).

\section{Conclusion}

Oat grain lipids on an industrial scale are isolated to obtain valuable oil due to its high-quality components (Pisulewska et al. 2011; Sahasrabudhe 1979). Oats as a phytosanitary plant have been used as feed in the past due to their high protein and fat content. Although the cultivation of oats has declined dramatically over the last 70 years, especially on mechanized farms, this cereal still remains important for the economies of developed and developing countries for special uses. So far, research on this crop has focused on the determination of nutrients such as fats, proteins and starch. Further research is needed to determine new functional compounds in oats as well as to find innovative solutions for the already known oat ingredients (Rasane et al. 2013). The oil contained in oats has not been used much so far, but thanks to the development of new methods and techniques for the fractionation of lipids, it allows to use its potential in the food industry (ErazoCastrejón et al. 2001), cosmetics (Harasym 2016) and pharmaceuticals (Moreau et al. 2008).
Funding Karol Banaś received doctoral grant within Interdisciplinary Doctoral Studies Program at the Faculty of Engineering and Economics of the Wrocław University of Economics (UEW) No. POWR.03.02.0000-IO16/16-00 Narodowe Centrum Badań i Rozwoju.

Open Access This article is licensed under a Creative Commons Attribution 4.0 International License, which permits use, sharing, adaptation, distribution and reproduction in any medium or format, as long as you give appropriate credit to the original author(s) and the source, provide a link to the Creative Commons licence, and indicate if changes were made. The images or other third party material in this article are included in the article's Creative Commons licence, unless indicated otherwise in a credit line to the material. If material is not included in the article's Creative Commons licence and your intended use is not permitted by statutory regulation or exceeds the permitted use, you will need to obtain permission directly from the copyright holder. To view a copy of this licence, visit http://creativecommons.org/licenses/by/4.0/.

\section{References}

Andersson, M. B. O., Demirbüker, M., \& Blomberg, L. G. (1997). Semicontinuous extraction/purification of lipids by means of supercritical fluids. Journal of Chromatography A, 785(1-2), 337-343. https:// doi.org/10.1016/S0021-9673(97)00083-6.

Aro, H., Järvenpää, E., Könkö, K., Huopalahti, R., \& Hietaniemi, V. (2007). The characterisation of oat lipids produced by supercritical fluid technologies. Journal of Cereal Science, 45(1), 116-119. https://doi.org/10.1016/j.jcs.2006.09.001.

Ballabio, C., Uberti, F., Manferdelli, S., Vacca, E., Boggini, G., Redaelli, R., Catassi, C., Lionetti, E., Peñas, E., \& Restani, P. (2011). Molecular characterisation of 36 oat varieties and in vitro assessment of their suitability for coeliacs' diet. Journal of Cereal Science, 54(1), 110-115. https://doi.org/10.1016/j.jcs.2011.04.004.

Batalova, G. A., Krasilnikov, V. N., Popov, V. S., \& Safonova E. E. (2019). Characteristics of the fatty acid composition of naked oats of Russian selection. IOP Conference Series: Earth and Environmental Science, 337, 1-6. https://doi.org/10.1088/17551315/337/1/012039.

Błaszczyk, K., Wilczak, J., Harasym, J., Gudej, S., Suchecka, D., Królikowski, T., Lange, E., \& Gromadzka-Ostrowska, J. (2015). Impact of low and high molecular weight oat beta-glucan on oxidative stress and antioxidant defense in spleen of rats with LPS induced enteritis. Food Hydrocolloids, 51, 272-280. https://doi.org/ 10.1016/j.foodhyd.2015.05.025.

Brindzová, L., Čertík, M., Rapta, P., Zalibera, M., Mikulajová, A., \& Takácsová, M. (2008). Antioxidant activity, $\beta$-glucan and lipid contents of oat varieties. Czech Journal of Food Sciences, 26(3), 163173. https://doi.org/10.17221/2564-cjfs.

Brown, C., \& Craddock, J. (1972). Oil content and groat weight of entries in the world oat collection1. Crop Science, 12(4), 514-515. https:// doi.org/10.2135/cropsci1972.0011183x001200040038x.

Doehlert, D. C., Moreau, R. A., Welti, R., Roth, M. R., \& McMullen, M. S. (2010). Polar lipids from oat kernels. Cereal Chemistry, 87(5), 467-474. https://doi.org/10.1094/CCHEM-04-10-0060.

Erazo-Castrejón, S. V., Doehlert, D. C., \& D’Appolonia, B. L. (2001). Application of oat oil in breadbaking. Cereal Chemistry, 78(3), 243-248. https://doi.org/10.1094/CCHEM.2001.78.3.243.

Fernández-Acosta, K., Salmeron, I., Chavez-Flores, D., Perez-Reyes, I., Ramos, V., Ngadi, M., et al. (2019). Evaluation of different variables on the supercritical CO2 extraction of oat (Avena sativa L.) oil; main fatty acids, polyphenols, and antioxidant content. Journal of Cereal Science, 88, 118-124. https://doi.org/10.1016/j.jcs.2019.05. 017. 
Flander, L., Salmenkallio-Marttila, M., Suortti, T., \& Autio, K. (2007). Optimization of ingredients and baking process for improved wholemeal oat bread quality. LWT - Food Science and Technology, 40(5), 860-870. https://doi.org/10.1016/j.lwt.2006.05.004.

Forssel, P., Kervinen, R., Alkio, M., \& Poutanen, K. (1992). Comparison of methods for separating polar lipids from oat oil. Fat Science Technology, 94(9), 355-358.

Frey, K., \& Hammond, E. (1975). Genetics, characteristics, and utilization of oil in caryopses of oat species. Journal of the American Oil Chemists Society, 52(9), 358-362. https://doi.org/10.1007/ BF02639196.

Frey, \& Holland. (1999). Nine cycles of recurrent selection for increased groat-oil content in oat. Crop Science, 39(6), 1636-1641. https://doi. org/10.2135/cropsci1999.3961636x.

Gangopadhyay, N., Hossain, M. B., Rai, D. K., \& Brunton, N. (2015). A review of extraction and analysis of bioactives in oat and barley and scope for use of novel food processing technologies. Molecules, 20(6), 10884-10909. https://doi.org/10.3390/molecules200610884.

Gilissen, L., van der Meer, I., \& Smulders, M. (2016). Why oats are safe and healthy for celiac disease patients. Medical Science, 4(4), 21. https://doi.org/10.3390/medsci4040021.

Gołębiewski. (2019). Systemy żywnościowe w warunkach gospodarki cyrkulacyjnej-Studium porównawcze krajów Unii Europejskiej. Warszawa: Wydawnictwo SGGW.

Gorash, A., Armoniene, R., Mitchell Feth, J., Liatukas, Ž., \& Danyte, V. (2017). Aspects in oat breeding: nutrition quality, nakedness and disease resistance, challenges and perspectives. Annals of Applied Biology, 171(3), 281-302. https://doi.org/10.1111/aab.12375.

Guan, X., Jin, S., Li, S., \& Huang, K. (2018). Antioxidant capacity of oat (Avena sativa L.) Bran. https://doi.org/10.3390/ molecules23071546.

Gupta, S., Cox, S., \& Abu-Ghannam, N. (2010). Process optimization for the development of a functional beverage based on lactic acid fermentation of oats. Biochemical Engineering Journal, 52(2-3), 199204. https://doi.org/10.1016/j.bej.2010.08.008.

Halima, N. B., Slima, A. B., Moalla, I., Fetoui, H., Pichon, C., Gdoura, R., \& Abdelkaf, S. (2014). Protective effects of oat oil on deltamethrin-induced reprotoxicity in male mice. The Royal Society of Chemistry, 5(9), 1-8. https://doi.org/10.1039/ c4fo00190g.

Halima, N. B., Saad, R. B., Khemakhem, B., Fendri, I., \& Abdelkafi, S. (2015). Oat (Avena sativa 1.): oil and nutriment compounds valorization for potential use in industrial applications. Journal of Oleo Science, 64(9), 915-932. https://doi.org/10.5650/jos.ess15074.

Harasym, J. (2011). Present status of oats in the gluten-free diet. Engineering sciences and technologies, 3(February), 57-70.

Harasym, J. (2015). Biorafinerie - rozwój konceptu. Przeglad ZbożowoMtynarski, 59(05), 2-4.

Harasym. (2016). http://www.biovelim.pl. Accessed 31 Jul 2020.

Holmback, J., Karlsson, A., \& Arnoldsson, K. (2001). Characterization of $\mathrm{N}$-acylphosphatidylethanolamine and acylphosphatidylglycerol in oats. Lipids, 36(2), 153-165. https://doi.org/10.1007/s11745-0010702-z.

Jacobsen, C. (2018). Oxidative rancidity. In Encyclopedia of food chemistry (pp. 261-269). Elsevier. https://doi.org/10.1016/B978-008-100596-5.21672-7.

Karunajeewa, H., Tham, S. H., \& Barr, A. (1989). Cultivars grown in three Australian states. Journal Science Food Agricultural, (Youngs 1978), 339-345.

Kawka, A., \& Achremowicz, B. (2014). Owies - roślina XXI wieku. Wykorzystanie żywieniowe i przemysłowe. Nauka Przyroda Technologie. Uniwersytet Przyrodniczy w Poznaniu, 8(3), 1-12.

Kusch, S., Schumacher, B., Oechsner, H., \& Schäfer, W. (2011). Methane yield of oat husks. Biomass and Bioenergy, 35(7), 26272633. https://doi.org/10.1016/j.biombioe.2011.02.044.
Lemons, E., Silva, C., Milach, S., Dos Anjos E Silva, S., \& Montero, C. (2008). Near infrared reflectance spectroscopy (NIRS) to assess protein and lipid contents in Avena sativa L. Crop Breeding and Applied Biotechnology, 8(2), 127-133. https://doi.org/10.12702/ 1984-7033.v08n02a05.

Liu, K. (2014). Fractionation of oats into products enriched with protein, beta-glucan, starch, or other carbohydrates. Journal of Cereal Science, 60(2), 317-322. https://doi.org/10.1016/j.jcs.2014.06.002.

Liukkonen, K. H., Laaksot, S. V., \& Montfoort, A. (1992). Waterinduced lipid changes in oat processing. Journal of Agricultural and Food Chemistry, 40(1), 126-130. https://doi.org/10.1021/ jf00013a024.

Manolache, F. A., Hanganu, A., Duta, D. E., Belc, N., \& Marin, D. (2013). The physico-chemical and spectroscopic composition characterization of oat grains and oat oil samples. Revista de Chimie, 64(1), 45-48.

Martínez-Villaluenga, \& Peñas. (2017). Health benefits of oat: current evidence and molecular mechanisms. Current Opinion in Food Science, 14, 26-31. https://doi.org/10.1016/j.cofs.2017.01.004.

McClements. (2015). Food emulsions principles, practices, and techniques.

McClements, D., \& Gumus, C. (2016). Natural emulsifiers biosurfactants, phospholipids, biopolymers, and colloidal particles: molecular and physicochemical basis of functional performance. Advances in Colloid and Interface Science. Elsevier B.V. 234, 3, 26 https://doi.org/10.1016/j.cis.2016.03.002.

Moltenberg, E., Vogt, G., Nilsson, A., \& Frolich, W. (1995). Effects of storage and heat processing on the content and composition of free fatty acids in oats. Cereal Chemistry, 72(1), 88-93.

Montealegre, C., Verardo, V., Gómez-Caravaca, A., García-Ruiz, C., Marina, M., \& Caboni, M. (2012). Molecular characterization of phospholipids by high-performance liquid chromatography combined with an evaporative light scattering detector, highperformance liquid chromatography combined with a flame ionization detector in different oat varieties. Journal of Agricultural and Food Chemistry, 60(44), 10963-10969. https://doi.org/10.1021/ jf302579j.

Moreau, R. A., Doehlert, D. C., Welti, R., Isaac, G., Roth, M., Tamura, P., \& Nuñez, A. (2008). The identification of mono-, di-, tri-, and tetragalactosyl-diacylglycerols and their natural estolides in oat kernels. Lipids, 43(6), 533-548. https://doi.org/10.1007/s11745-0083181-6.

Musa Özcan, M., Özkan, G., \& Topal, A. (2006). Characteristics of grains and oils of four different oats ( Avena sativa L.) cultivars growing in Turkey. International Journal of Food Sciences and Nutrition, 57(5-6), 345-352. https://doi.org/10.1080/09637480600802363.

Peterson, D. (2001). Oat antioxidants. Journal of Cereal Science, 33(2), 115-129. https://doi.org/10.1006/jcrs.2000.0349.

Peterson, D., \& Wood, D. (1997). Composition and structure of high-oil oat. Journal of Cereal Science, 26(1), 121-128.

Piątkowska, E., Witkowicz, R., \& Pisulewska, E. (2010). Podstawowy skład chemiczny wybranych odmian owsa siewnego. Żywność. Nauka. Technologia. Jakość/Food. Science. Technology. Quality, 17(3), 88-99.

Pisulewska, E., Tobiasz-Salach, R., Witkowicz, R., Cieślik, E., \& Bobrecka-Jamro, D. (2011). Wpływ warunków siedliska na ilość i jakość lipisów w wybranych formach owsa. Żywność. Nauka. Technologia. Jakość, 3(76), 66-77.

Price, P. B., \& Parsons, J. G. (1975). Lipids of seven cereal grains. Journal of the American Oil Chemists Society, 52(12), 490-493. https://doi.org/10.1007/BF02640738.

Ralla, T., Salminen, H., Edelmann, M., Dawid, C., Hofmann, T., \& Weiss, J. (2018). Oat bran extract (Avena sativa L.) from food byproduct streams as new natural emulsifier. Food Hydrocolloids, 81, 253-262. https://doi.org/10.1016/j.foodhyd.2018.02.035. 
Rasane, P., Jha, A., Sabikhi, L., Kumar, A., \& Unnikrishnan, V. S. (2013). Nutritional advantages of oats and opportunities for its processing as value added foods - a review. Journal of Food Science and Technology, 52(2), 662-675. https://doi.org/10.1007/s13197013-1072-1.

Roggo, Y., Chalus, P., Maurer, L., Lema-Martinez, C., Edmond, A., \& Jent, N. (2007). A review of near infrared spectroscopy and chemometrics in pharmaceutical technologies. Journal of Pharmaceutical and Biomedical Analysis, 44(3 SPEC. ISS.), 683700. https://doi.org/10.1016/j.jpba.2007.03.023.

Saastamoinen, M., Kumpulainen, J., \& Nummela, S. (1989). Genetic and Environmantal variation in oil content and fatty acid composition of oats. Cereal Chemistry.

Sahasrabudhe, M. R. (1979). Lipid composition of oats (Avena sativa L.). Journal of the American Oil Chemists' Society, 56(2), 80-84. https:// doi.org/10.1007/BF02914274.

Sang, S., \& Chu, Y. (2017). Whole grain oats, more than just a fiber: role of unique phytochemicals. Molecular Nutrition \& Food Research, 61(7), 1-31. https://doi.org/10.1002/mnfr.201600715.

Sibakov, J., Myllymäki, O., Holopainen, U., Kaukovirta-Norja, A., Hietaniemi, V., Pihlava, J. M., Poutanen, K., \& Lehtinen, P. (2011). Lipid removal enhances separation of oat grain cell wall material from starch and protein. Journal of Cereal Science, 54(1), 104-109. https://doi.org/10.1016/j.jcs.2011.04.003.

Sterna, V., Zute, S., Brunava, L., \& Vicupe, Z. (2014). Lipid composition of oat grain grown in Latvia. In 9th Baltic Conference on Food Science and Technology "Food for Consumer Well-Being" (pp. 77-80). Jelgava. https://doi.org/10.13140/2.1.5172.1605.

Suchecka, D., Harasym, J. P., Wilczak, J., Gajewska, M., Oczkowski, M., Gudej, S., Błaszczyk, K., Kamola, D., Filip, R., \& GromadzkaOstrowska, J. (2015). Antioxidative and anti-inflammatory effects of high beta-glucan concentration purified aqueous extract from oat in experimental model of LPS-induced chronic enteritis. Journal of Functional Foods, 14, 244-254. https://doi.org/10.1016/j.jff.2014. 12.019 .

Suchecka, D., Harasym, J., Wilczak, J., \& Gromadzka-Ostrowska, J. (2016). Hepato- and gastro- protective activity of purified oat $1-3$, $1-4-\beta$-D-glucans of different molecular weight. International Journal of Biological Macromolecules, 91. https://doi.org/10. 1016/j.ijbiomac.2016.06.062.

Suchecka, D., Błaszczyk, K., Harasym, J., Gudej, S., Wilczak, J., \& Gromadzka-Ostrowska, J. (2017). Impact of purified oat 1-3,1-4$\beta$-d-glucan of different molecular weight on alleviation of inflammation parameters during gastritis. Journal of Functional Foods, 28 , 11-18. https://doi.org/10.1016/j.jff.2016.10.028.
Tong, L., Zhong, K., Liu, L., Guo, L., Cao, L., \& Zhou, S. (2014). Oat oil lowers the plasma and liver cholesterol concentrations by promoting the excretion of faecal lipids in hypercholesterolemic rats. Food Chemistry, 142, 129-134. https://doi.org/10.1016/j.foodchem. 2013.07.028

UN. (2015). Przekształcamy nasz świat: Agenda na rzecz zrównoważonego rozwoju 2030.

Walters, M., Lima Ribeiro, A. P., Hosseinian, F., \& Tsompo, A. (2018). Phenolic acids, avenanthramides, and antioxidant activity of oats defatted with hexane or supercritical fluid. Journal of Cereal Science, 79, 21-26. https://doi.org/10.1016/j.jcs.2017.09.010.

Wang, H. C., Hung, C. H., Hsu, J. D., Yang, M. Y., Wang, S. J., \& Wang, C. J. (2011). Inhibitory effect of whole oat on aberrant crypt foci formation and colon tumor growth in ICR and BALB/c mice. Journal of Cereal Science, 53(1), 73-77. https://doi.org/10.1016/j. jcs.2010.09.009.

Welch, R. (1977). A micro-method for the estimation of oil content and composition in seed crops. Journal of the Science of Food and Agriculture, 28(7), 635-638. https://doi.org/10.1002/jsfa. 2740280710

Wilde, P. J., Garcia-Llatas, G., Lagarda, M. J., Haslam, R. P., \& Grundy, M. M. L. (2019). Oat and lipolysis: food matrix effect. Food Chemistry, 278(November), 683-691. https://doi.org/10.1016/j. foodchem.2018.11.113.

Younes, M., Aquilina, G., Castle, L., Engel, K. H., Fowler, P., Frutos Fernandez, M. J., et al. (2020). Safety of use of oat lecithin as a food additive. EFSA Journal, 18(1), 1-22. https://doi.org/10.2903/j.efsa. 2020.5969.

Youngs, V. L., Püskülcü, M., \& Smith, R. R. (1977). Oat lipids. I. Composition and distribution of lipid components in two oat cultivars. Cereal Chemistry.

Zhou, M., Holmes Glennie, M., Robards, K., \& Helliwell, S. (1998). Fatty acid composition of lipids of Australian oats. Journal of Cereal Science, 28(3), 311-319. https://doi.org/10.1016/S07335210(98)90011-X.

Zhou, M., Robards, K., Glennie-Holmes, M., \& Helliwell, S. (1999). Oat lipids. JAOCS, Journal of the American Oil Chemists' Society, 76(2), 159-169. https://doi.org/10.1007/s11746-999-0213-1.

Zieliński, H., Achremowicz, B., \& Przygodzka, M. (2012). Przeciwutleniacze Ziarniaków Zbóż. Zywnosc. Nauka. Technologia. Jakosc/Food. Science Technology. Quality, 19(1), 526.

Publisher's Note Springer Nature remains neutral with regard to jurisdictional claims in published maps and institutional affiliations. 